SEDA Spring Teaching Learning and Assessment

Conference 2014

Engaging Students: Engaging Staff

Copthorne Hotel Newcastle

$15^{\text {th }}-16^{\text {th }}$ May 2014

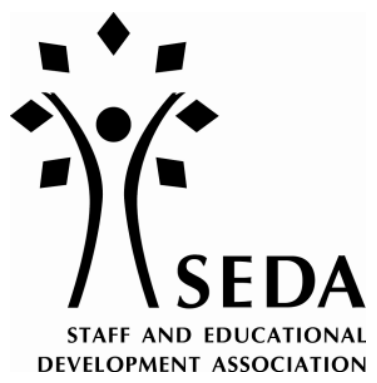

\title{
Proposal Form
}

Proposals should be submitted electronically to the SEDA office at

conferences@seda.ac.uk by Monday $4^{\text {th }}$ November 2013.

Name(s) of presenters: EVE RAPLEY

Institution(s): UNIVERSITY OF BEDFORDSHIRE

Address for correspondence:

Tel: 07886244894

E-mail: EVE.RAPLEY@BEDS.AC.UK

Title of proposal: Horses for courses or a grumble in the jungle? HE in FE student perceptions of the HE experience in a Landbased college

Format:

Poster session

Session Learning Outcomes

By the end of this session, delegates will be able to:

- haVe GAINED INSIGHT INTO HE in FE STUDENT PERCEPTIONS OF THEIR EXPERIENCES OF STUDYING HE IN AN FE (LANDBASED) COLLEGE ENVIRONMENT

- BEGIN TO APPRECIATE THE UNDERLYING TENSIONS AND DIFFICULTITES THAT EXIST WHEN DELIVERING HE WITHIN AN FE COLLEGE

- CONSIDER THE CULTURAL DiMENSIONS OF FE AND HE AND HOW THEIR INTERPLAY CAN ADVERSELY AFFECT THE EXPERIENCE OF HE in FE STUDENTS

Session Outline (no more than 300 words)

The poster will present a summary of preliminary findings regarding the perceptions of the legitimacy and quality of the HE student experience through the lens of those studying Animal/Equine Studies Foundation Degrees and BSc degrees within a small, ostensibly FE Landbased college setting.

As part of a PhD study, research data was collected using two student focus groups. Empirical student perception data from Animal/Equine Studies students gathered 
whilst discharging External Examiner duties at six English FE Landbased colleges from 2007-2013 was also included.

Despite FE college claims regarding the 'supportive environment' and 'small classes' being the USP for those studying HE in FE (as opposed to HE within the university sector), responses from Animal/Equine Studies students reported dissatisfaction with regard to the predominating FE culture, as well as concerns surrounding their $\mathrm{HE}$ status and the perception of others, as being bona fide HE students. Drawing on Bourdieu's conceptual framework of habitus and field and notions of an institutional habitus, the $\mathrm{HE}$ in FE student experience is contextualised, together with recommendations for enriching $\mathrm{HE}$ in FE from the student perspective.

With an increasing push for more HE in FE provision, this study is timely and could help to inform the HE in FE experience for students across the UK.

\section{Session Activities and Approximate Timings}

Poster will have sections outlining background to study, a mini lit review, methodology, results and findings from the student focus groups and a discussion and recommendations section.

\section{References}

Aldous, D and Westrup, R. 2012. Building knowledge across boundaries: Policy as lived experience within the FEHE context" Conference report. 11th June 2012 at the School of Education and Lifelong Learning, University of East Anglia.

Bourdieu, P. 1984. Distinction: a social critique of the judgement of taste. London: Routledge

Bourdieu, P. 1990. Structures, habitus, practices. In P. Bourdieu, The logic of practice Stanford, CA: Stanford University Press

Bourdieu, P and Wacquant, L.J.D. 1992. An Invitation to Reflexive Sociology. Chicago: Univ. Chicago Press

Burns, D. 2007. Conceptualising and interpreting organizational boundaries between further and higher education in 'dual sector' institutions: where are they and what do they do? International Conference on researching transitions in lifelong learning, university of Stirling 22-24 June 2007

Cable, V. 2012. Putting the HE in FE at AoC Conference (13 April 2012) Available at: feweek.co.uk/2012/04/13/putting-the-he-in-fe-at-aoc-conference/ (date accessed 10/5/2012).

Cockburn, J. 2006. A Case Study of City College Norwich in The role of regional further education colleges delivering higher education in east of England, Full Report Available at: www.theresearchcentre.co.uk/files/docs/publications/he0005.pdf (date accessed 18/3/2012).

Creasy, R. 2013. HE lite: exploring the problematic position of HE in FECs, Journal of Further and Higher Education Vol. 37, No. 1, 38-53.

Darko-Ampem, K. 2010. HE in FE @ South Thames College - conference review Partnerships for higher education in further education: the library perspective 
Available at: www.uwe.ac.uk/library/info/conf/heinfeconference.htm (date accessed $6 / 5 / 2012)$.

Davies, P. 2010. No more condescension, please Available at: www.timeshighereducation.co.uk/story. asp?storyCode $=411524 \&$ sectioncode $=26$ (date accessed 30/9/2012).

Feather, D. 2010. A whisper of academic identity: an HE in FE perspective Research in Post-Compulsory Education Vol. 15 No. 2 June 2010 pp 189-204.

Feather, D. 2013. Has Cinderella Become so Fragmented That She Can No Longer Identify her Area of Expertise European Journal of Education, DOI:

10.1111/ejed.12047

Fenge, L. 2011. "A second chance at learning but it's not quite higher education": experience of a foundation degree Journal of Further and Higher Education Vol. 35 No. 3 pp 375-390.

Frampton, R. 2009. Borderless or Bound? Exploring students' perceptions of HE in FE learning spaces $4^{\text {th }}$ International Inquiring Pedagogies Conference 'Researching Beyond Boundaries', Academic Communities without Borders 14 - 15 September 2009, Coventry University, UK.

Fraser, M, Orange, G, Ah-Lian, K \& Stone, M. 2009. The creation, operation and future of $H E$ in FE partnerships Conference: HE in FE culture and experience: a partnership perspective, Warwick, 30th - 31st March 2009. Available at:

http://uplace.org.uk:8080/dspace/handle/10293/165 (date accessed 2/10/2012).

Golding Lloyd, M and Griffiths, C. 2008. A review of the methods of delivering HE programmes in an FE college and an evaluation of the impact this will have on learning outcomes and student progression Journal of Further and Higher Education, Vol. 32, No. 1, February 2008, 15-25.

Higher Education Academy (HEA). 2006. HE experience of NQF BTEC Higher National learners in Further Education colleges Available at:

www.ics.heacademy.ac.uk/HEinFE/.../HEExperienceVersion7.pdf (date accessed $18 / 11 / 2012$ )

Jones, R. 2006. A Higher Education Ethos - A review of information and literature relating to the creation of an ethos of HE in the context of FE. Available at:

www.ics.heacademy.ac.uk/HEinFE/.../A Higher Education Ethos.doc (date accessed 4/7/2011).

King, M and Widdowson, J. 2012. Inspiring individuals: teaching higher education in a further education college. Exploring the pedagogy of HE delivered in an FE setting.

Available at:

www.heacademy.ac.uk/resources/detail/heinfe/Inspiring individuals MEG (date accessed 6/8/2012).

Lea, J and Simmons, J. 2012. Higher Education in Further Education: capturing and promoting HEness', Research in Post-Compulsory Education Volume 17, Issue 2

Leahy, S.M. 2012. The barbarians at the gate. Playing the higher education game: observations from the periphery of the field Journal of Further and Higher Education, $36(2)$. 
Murray, J. 2010. FE colleges win students from universities The Guardian, Tuesday $8^{\text {th }}$ June. Available at: www.guardian.co.uk/education/2010/jun/08/further-educationcollege-degrees (date accessed 29/1/2013).

Nash, R.1999. Bourdieu, 'Habitus' and educational research: Is it all worth the candle?' Brit. J. Sociol. Educ., 20: 175-281

National Union of Students (NUS). 2011. HE in FE Available at: www.nusconnect.org.uk/campaigns/highereducation/nss/he-in-fe/ (date accessed 2/3/2013).

Parry, G, Callender, C, Scott, P and Temple, P. 2012. Understanding higher education in further education institutions Department for Business, Innovation and Skills, Research paper number 69 (June 2012). Available at: www.bis.gov.uk (date accessed 14/7/2012).

Reay, D, David M and Ball, S. 2001. Making a Difference?: Institutional Habituses and Higher Education Choice. Sociological Research Online, vol. 5, no. 4. Available at: www.socresonline.org.uk/5/4/reay

Rapley, E. 2012. HE in FE - past, present and future Journal of Pedagogic Development Volume 2, Issue 2 June 2012. Available at: www.beds.ac.uk/ data/assets/pdf file/0020/.../HE-in-FE.pdf (date accessed 15/7/2012).

Robinson, D 2012 Higher Education in Further Education: student perceptions of the value of foundation degree qualifications Journal of Further and Higher Education , 17 (4), pp. 453-469.

Robinson, D. and Noel, P. 2009 'The HE in FE experience and culture for students'. In: HE in FE culture and experience: a partnership perspective, 30th - 31st March 2009, University of Warwick, Warwick, UK.

Skinner, J, Souch, L and Gill, J. 2013. HE in FE. What is it and what can it offer? Available at: www.exeter.ac.uk/media/universityofexeter Ladmissionsandukstudentrecruitment/sro/HE in FE Feb 13.ppt (date accessed 13/3/2013).

Struthers, C. 2010. The Benefits of Studying HE in FE. Published by Yorkshire \& Humber East Lifelong Learning Network (Hull College). Available at: www.lifelonglearningnetworks.org.uk/.../benefits-of-he-in-fe.doc (date accessed 21/2/2013)

Tierney, S \& Slack, K. 2005. "Learning journeys: the experiences of students working towards a foundation degree", Journal of Vocational Education and Training, Vol 57, No 3, pp375-388.

Thomas, L. 2002. Student retention in higher education: the role of institutional habitus. Journal of Education Policy 17(4): 423-442

Weissmann, E. 2013. Excluded from the institutional habitus: the joint student experience. Journal of Further and Higher Education, 37:2, 261-279 
West, J. 2006. Patrolling the borders: accreditation in further and higher education in England. Journal of Further and Higher Education Vol. 30, No. 1, February 2006, pp. $11-26$

Wainright, S.P, Williams, C and Turner, B. S 2006. Varieties of habitus and the embodiment of ballet Qualitative Research 2006 SAGE Publications (London, Thousand Oaks and New Delhi vol. 6(4) 535-558

Young, P. 2002. 'Scholarship is the word that dare not speak its name': Lecturers' experiences of teaching on a higher education programme in a further education college. Journal of Further and Higher Education, 26 (3). pp. 273-286. 